\title{
ACKNOWLEDGMENT PATTERNS IN ENGLISH AND LITHUANIAN RESEARCH WRITING
}

\author{
Jolanta Šinkūnienè and Gabrielè Dudzinskaitè
}

\begin{abstract}
The paper focuses on the features of acknowledgments in scientific texts written by British and Lithuanian authors in the Humanities. The data comes from a self-compiled corpus of acknowledgments in scientific books written by British and Lithuanian researchers in their native languages, and from doctoral dissertations written by Lithuanian doctoral students in Lithuanian. The results of the quantitative and qualitative analysis suggest that the British scholars place more importance on acknowledgments as they single out their thanks as separate sections, make them longer and express gratitude for a larger number of individuals and institutions than the Lithuanian scholars. Generally the same moves and steps are employed in the three data sets, but the distribution of some moves and steps is different.
\end{abstract}

\section{Keywords}

acknowledgments, scientific books, PhD theses, Lithuanian, English

\section{Introduction}

A growing interest in research writing worldwide has resulted in a number of studies that reveal not only universal features of academic discourse, but also trends typical to specific cultures (Duszak 1997, Fløttum et al. 2006, SuomelaSalmi \& Dervin 2009). Differences between the so-called 'form-oriented' vs 'content-oriented' cultures (Clyne 1987) or 'reader-responsible' vs 'writerresponsible' (Hinds 1987) styles of writing point at a different conceptualization of the reader-writer roles and relationships in different cultures, as well as a number of differences in structuring and presenting scientific argument. Following Holliday (1999), Atkinson $(2003,2004)$ argues that next to the national or 'big' culture, the so-called 'small' cultures, such as classroom culture or professionalacademic culture, have to be taken into account as well. Numerous crossdisciplinary studies on academic discourse (Hyland 2005, Hyland \& Bondi 2006, Hyland 2008, inter alia) indeed show that there are certain rhetorical practices characteristic of one science field, but not typical of the other, thus justifying the concept of 'disciplinary culture' suggested by Mauranen (1993).

Cultural or disciplinary aspects are not the only ones playing an important role in shaping up academic texts. Textual genres have a significant influence 
on the linguistic choices both on macro and micro levels of text construction as well. Studies on moves and steps in various rhetorical sections of academic texts, stance and metadiscourse markers in textbooks and research articles or $\mathrm{PhD}$ theses (Hopkins \& Dudley-Evans 1988, Swales 2004, Hyland 2005, Hyland 2009), features of conference and research article abstracts (Lorés 2004, Bondi \& Lorés-Sanz 2014, Povolná 2016), show that there are important features of academic text predetermined by the genre irrespective or alongside culture or discipline.

While there are many studies on the well established genres, such as research articles or abstracts, much less attention has been devoted to the genre of acknowledgments (Hyland 2004). Hyland (2003: 1) argues that even though acknowledgments with their clear aims and structure are becoming a set genre in academia, they still constitute the so-called 'Cinderella' genre which lacks greater attention. He foregrounds the importance of this genre, pointing out a number of insights one can obtain about academic disciplines and cultures, professional and personal identities, persuasion strategies and hidden influences by studying acknowledgments (Hyland 2003, Hyland \& Tse 2004). For example, cross-disciplinary comparisons reflect interesting influences of the nature of the science field on acknowledgments. More individualistic soft fields rely on cooperation and networking to a smaller extent than hard fields and therefore have fewer acknowledgments (Cronin et al. 1993, Hyland 2003) as well as rely on different types of support provided (Diaz-Faes \& Bordons 2014).

Research on acknowledgments suggests that there are differences not only in different science fields, but also in different cultures. Cheng's (2012) contrastive study of Master thesis acknowledgments written by Taiwanese and North American students reveals that Taiwanese students use more explicit and more complex academic writing strategies than North American students. The study also shows that Taiwanese students' acknowledgments are lengthier. Cheng suggests that Taiwanese students consider acknowledgments to be very formal, and, therefore, more complex language is thought to be more appropriate. In his study of Italian and English acknowledgments in research articles, Giannoni (2002) shows that Italian authors favour impersonal constructions in certain moves, while English authors employ a wider range and more overt thanking expressions. Based on 60 English and Lithuanian research articles in four disciplines, Šinkūnienè's (2014) study suggests that Lithuanian scholars use very few acknowledgments in comparison to the English native speakers.

Considerable research has been devoted to acknowledgments in research articles and $\mathrm{MA} / \mathrm{PhD}$ theses, however less attention has been paid to acknowledgments in scientific books, especially from a contrastive perspective. 
The aim of this study, therefore, is to analyse features of acknowledgments from cross-linguistic and cross-generic perspectives. The focus of the study is on the structural patterns of gratitude expression in the acknowledgments in two different genres ( $\mathrm{PhD}$ dissertations vs scientific books) and two different academic cultures (British and Lithuanian).

\section{Data and methods}

The study is based on a self-compiled corpus of 132 texts of acknowledgments in two languages and two genres within the field of Humanities. The analysed acknowledgments come from 100 scientific books written by British and Lithuanian researchers in their native languages, and from 32 doctoral dissertations written by Lithuanian doctoral students in Lithuanian. The corpus was compiled following the guidelines for designing specialised comparable corpora (Bowker \& Pearson 2002, Connor \& Moreno 2005).

Only single authored scientific books were selected. The authors of the texts had to be native speakers of British English and Lithuanian, the work had to be published between 2007 and 2017, and only one text of each author was selected for individual sub-corpora. Following Sala (2008), the native speaker status for the British researchers was determined by searching for the authors' biographical information on the web. If the author received his/her full education in Britain, his/her acknowledgments were included into the corpus. The cultural background of Lithuanian authors was easier to identify by the last name; however, if in doubt, the author's biographical information was also checked on the web.

Although the gender of the author was not the focus of the study, an attempt was still made to balance the corpus for female and male authors to avoid the potential influence of gender on the results. This was possible for the scientific books sub-corpus, especially for the British English part which includes acknowledgments written by 25 female and 25 male authors. The sub-corpus of scientific books in Lithuanian follows closely with 28 female and 22 male authors. However, to observe the gender aspect in $\mathrm{PhD}$ dissertations was impossible due to the limitations of the available material, which yielded acknowledgments written by 28 female and four male authors.

The British English sub-corpus consists of acknowledgments from 50 scientific books in the Humanities collected from one publisher, Cambridge Scholars Publishing (CSP). CSP (http://www.cambridgescholars.com) is an independent academic publisher, which publishes scientific work across a range of disciplines. CSP lists all the published volumes online; in the process of data collection, scientific books in the Humanities were checked one by one, first of all to see if they had acknowledgments, and then if the author was a native 
British English speaker. If those and the other criteria mentioned above were met, the acknowledgment was included into the corpus. The sub-corpus features acknowledgments from Linguistics, Literature, Film and Theatre Studies, Classics, Cultural Studies, Philosophy, Fine Arts, Music, Archaeology.

The Lithuanian sub-corpus consists of 50 scientific books and 32 doctoral dissertations written in the Lithuanian language. The data collection for the subcorpus of Lithuanian scientific books was not easy because there are far less academic books published in Lithuanian than in English, and some publishing houses specialise just in one discipline of the Humanities rather than in many. As a result, the data for the sub-corpus was collected from twelve different publishing houses ${ }^{1}$. The acknowledgments collected in the sub-corpus are from such disciplines as History, Literature, Linguistics, Arts, Philosophy. Lithuanian doctoral dissertations were selected from the webpage of the Research Council of Lithuania, which chronologically lists all dissertations defended in Lithuania. The procedure for the selection of acknowledgments from dissertations was exactly the same as for the British English sub-corpus. A total of 267 doctoral dissertations in the Humanities satisfying the selection criteria were found, but only 32 of them (i.e. 12\%) contained acknowledgments. This explains a different number of texts for this sub-corpus. The disciplinary background of the authors who wrote acknowledgments in their doctoral dissertations was Philology, Philosophy, Ethnology, History, Theology, Arts, Communication.

During the data collection process we discovered that authors of Lithuanian scientific books, unlike the British researchers, did not tend to single out their acknowledgments as a separate section, but predominantly included their gratitude in the Foreword of the book. The Foreword section typically presents various aspects related to the book, such as the book background, theoretical framework, structural parts of the book and their rationale, reference to other related works, among other things. The section could span from half a page to many pages in length, therefore for this analysis it was decided to take only that part of the Foreword, which started with the direct acknowledgment. The English books and the Lithuanian $\mathrm{PhD}$ dissertations contained sections called Acknowledgments, but these sections sometimes also included some background information on the book or thesis, so in order to make all three data sets comparable, only the parts where the actual acknowledgments started were selected for further analysis.

The size of the corpus used for the study is slightly more than 28,000 words (Table 1). 
Acknowledgment Patterns in English and Lithuanian Research Writing

\begin{tabular}{|l|l|l|l|}
\hline Sub-corpus & Texts & Words & Mean length (words) \\
\hline Scientific books in English & 50 & 15,031 & 300.6 \\
\hline Scientific books in Lithuanian & 50 & 8,387 & 167.7 \\
\hline Lithuanian doctoral dissertations & 32 & 4,734 & 147.9 \\
\hline Total & 132 & 28,152 & 213.3 \\
\hline
\end{tabular}

Table 1: The size and composition of the Acknowledgments corpus

The study employs corpus-based contrastive methodology as well as quantitative and qualitative analysis. Following Hyland (2004) and Hyland and Tse (2004), semi-structured interviews were conducted with six researchers from the Humanities (History, English Philology, Lithuanian Philology). The interview grid consisted of seven open questions focusing on the interviewees' views on the importance of gratitude expression in the academia, acknowledgment trends dominating in their disciplinary field as well as on their own practices in acknowledging. As there is a considerable lack of research into Lithuanian scholars' practices of acknowledging, only Lithuanian researchers were interviewed. The interviews were conducted in the Lithuanian language, the cited fragments of the interviews were translated into English by the authors of the paper. For the analysis of the structural patterns of acknowledgments Hyland's (2004) model of rhetorical Moves and Steps was employed (Section 3.1 presents the model in more detail).

The examples provided in the paper are coded using $E N$ or $L T$ for the cultural background of the author, abbreviations $S B$ for scientific books and $P h D$ for doctoral dissertations, as well as the text number. The coding for the structural parts uses $M$ for the moves and $S$ for the steps identified.

\section{Results and discussion}

The results of the study suggest that there is more significance placed on written acknowledgments in the English academic tradition than in Lithuanian. This has already become evident in the process of data selection as there was a difficulty to find acknowledgments as a separate section in Lithuanian scientific books. The tendency not to devote a separate section for acknowledgments has also been noted by the interviewees:

In Lithuania there is no tradition to have a separate section for acknowledgments. Typically, they are provided at the end of the Foreword. (Interviewee 1, History) 
So far as doctoral dissertations in Lithuanian are concerned, it was not possible to collect the sample of texts equivalent to the books sub-corpus sample as in the time span of ten years only twelve per cent of dissertations had acknowledgments sections. This is perhaps a surprising finding, as writing acknowledgments seems to be especially characteristic of PhD work as it "offers students a unique rhetorical space to both convey their genuine gratitude for assistance and to promote a capable academic and social identity" (Hyland \& Tse 2004: 259). This is also in a stark contrast with the results of Hyland and Tse (2004), where 98 per cent of $\mathrm{PhD}$ dissertations written by students at Hong Kong universities had an acknowledgment.

An interesting aspect which was revealed in the process of data collection was a different trend for Humanities dissertations written by Lithuanian doctoral students, but in English, not Lithuanian. In the time span selected there were 13 dissertations written in English, and nine of them (69\%) contained an acknowledgments section. It may be that the doctoral students who are exposed to the English writing traditions more are also influenced by those traditions.

The mean length of acknowledgments in the three sub-corpora confirms similar trends. Acknowledgments are nearly twice lengthier in the analysed English scientific books (300.6 words on average) than in the Lithuanian scientific books and in doctoral dissertations (see Table 1 above). The longest thanking text in the sub-corpus of doctoral dissertations is 279 words, in the sub-corpus of scientific books in Lithuanian it amounts to 552 words, whereas the longest acknowledgments text written by a British researcher is 2,024 words.

These results suggest that the English authors of the analysed texts treat acknowledgments as an essential part of the research process; their importance is foregrounded by devoting a special section for them. A very small number of acknowledgments found in $\mathrm{PhD}$ dissertations seems to suggest that novice Lithuanian researchers do not have a tradition to include written acknowledgments in their theses. It does not mean, however, that Lithuanian doctoral students do not receive support or are not grateful for it. According to our interviewees, there is a tradition to express gratitude after the dissertation's defence orally, especially since the $\mathrm{PhD}$ thesis is considered to be unpublished work:

You think that the PhD thesis will still be defended and you will have an opportunity to thank orally, because finishing writing your dissertation is not the final point. If I had written a monograph, I would have included acknowledgments, because I would not have had an opportunity to express my thanks orally. (Interviewee 3, Lithuanian Philology) 
Dissertation is not a book, it does not have an ISBN code, that is why acknowledgments are expressed orally. When people publish a book based on the dissertation, then acknowledgments are necessarily there. (Interviewee 1, History)

A different view, however, is expressed by scholars from English Philology:

It is especially the PhD thesis where it is important to express acknowledgments properly. Writing a dissertation is a long process, you meet a lot of people in your academic career and it is natural to want to thank them. You want to express your gratitude to your supervisor, your family. (Interviewee 5, English Philology)

Interviews with scholars from Lithuanian and English Philology also point towards diverging tendencies of what is expected from students in terms of expressing thanks in writing. Researchers who presumably are exposed to the Lithuanian writing tradition more are not surprised that students do not write acknowledgments:

I would never allow my students to thank me as a supervisor, because it seems to me that it is self-evident. It would be very strange to me. (Interviewee 2, Lithuanian Philology)

However, the interviewees who are used to the English writing tradition treat acknowledgments as an essential part of academic life. They believe that to include acknowledgments in any research writing should be a common practice:

Even in BA papers acknowledgments probably should be present $<\ldots$. . It is a kind of recognition of the work of the supervisor, it indicates who was leading the work, who pointed you to a particular direction. (Interviewee 5, English Philology)

I would feel bad if I would not be acknowledged for my help. I don't like works that do not have acknowledgments. Acknowledgments should be a required part of academic genres. (Interviewee 4, English Philology)

In this section very general tendencies were presented. The following sections will look at the specific moves and patterns of gratitude expression in more detail.

\subsection{The generic structure of acknowledgments}

Hyland's (2004) model of the generic structure of acknowledgments distinguishes three main moves, namely, the Reflecting move where the author usually gives some comments on his or her research experience, the Thanking 
move and the Announcing move, both of which can be broken into smaller steps (Table 2):

\begin{tabular}{|l|l|}
\hline 1 Reflecting move & $\begin{array}{l}\text { Introspective comments on the writer's research } \\
\text { experience }\end{array}$ \\
\hline 2 Thanking move & Mapping credit to individuals and institutions \\
\hline 2.1 Presenting participants & Introducing those to be thanked \\
\hline $\begin{array}{l}2.2 \text { Thanking for academic } \\
\text { assistance }\end{array}$ & $\begin{array}{l}\text { Thanks for intellectual support, ideas, analyses, } \\
\text { feedback, etc. }\end{array}$ \\
\hline 2.3 Thanking for resources & $\begin{array}{l}\text { Thanks for data access \& clerical, technical and financial } \\
\text { support }\end{array}$ \\
\hline 2.4 Thanking for moral support & $\begin{array}{l}\text { Thanks for encouragement, friendship, sympathy, } \\
\text { patience, etc. }\end{array}$ \\
\hline 3 Announcing move & Public statement of responsibility and inspiration \\
\hline 3.1 Accepting responsibility & An insertion of authorial responsibility for flaws or errors \\
\hline 3.2 Dedicating the thesis & A formal dedication of the thesis to an individual(s) \\
\hline
\end{tabular}

Table 2: Move structure of dissertation acknowledgments (adapted from Hyland 2004: 308)

As explained in the Data and methods section, due to data compatibility reasons we had to start the analysis directly from the Thanking move, which Hyland (2004) considers to be the only obligatory move in the acknowledgments rhetorical structure. We have also singled out the Announcing move wherever it was present.

\begin{tabular}{|l|l|l|l|}
\hline Moves and steps & EN books & LT books & LT dissertations \\
\hline 2 Thanking move & $100 \%$ & $100 \%$ & $100 \%$ \\
\hline 2.1 Presenting participants & $64 \%$ & $50 \%$ & $41 \%$ \\
\hline 2.2 Academic assistance & $94 \%$ & $100 \%$ & $100 \%$ \\
\hline 2.3 Resources & $90 \%$ & $86 \%$ & $72 \%$ \\
\hline 2.4 Moral support & $76 \%$ & $68 \%$ & $100 \%$ \\
\hline 3 Announcing move & $58 \%$ & $34 \%$ & $6 \%$ \\
\hline
\end{tabular}


Acknowledgment Patterns in English and Lithuanian Research Writing

\begin{tabular}{|l|l|l|l|}
\hline Moves and steps & EN books & LT books & LT dissertations \\
\hline $\begin{array}{c}3.1 \text { Accepting } \\
\text { responsibility }\end{array}$ & $8 \%$ & $10 \%$ & $6 \%$ \\
\hline 3.2 Dedication & $58 \%$ & $28 \%$ & 0 \\
\hline
\end{tabular}

Table 3: The distribution of moves and steps across the sub-corpora (\%)

The results in Table 3 show the percentage of the texts in each of the three sub-corpora that contain at least one particular move or step. We can see that the Thanking move is the core move of the analysed acknowledgments with every text including it in the form of one step or several steps. This is hardly surprising as thanking is the actual purpose of this section. The distribution of the steps in Move 2, however, reflects different aspects scholars feel grateful for in the two genres. While thanks for academic assistance dominate in this move in scientific books in both languages, the doctoral students feel equally grateful for moral support. Thanking for various resources is included in nearly all scholarly books, whereas $\mathrm{PhD}$ students seem to rely on external resources to a smaller extent. Hyland's (2004) disciplinary study of PhD dissertations shows similar trends with thanking for resources being the least frequent move, and thanking for academic assistance appearing in 100 per cent of the cases.

Table 3 above shows how many texts in the sample contained one or another move or step at least once. However, some moves or steps were recurring, sometimes many times within one text of acknowledgments. The frequency of the overall occurrence of the three major steps $(2.2-2.4)$ of the Thanking move is presented in Table 4.

\begin{tabular}{|l|l|l|l|l|l|l|}
\hline & \multicolumn{2}{|l|}{ EN books } & \multicolumn{2}{l|}{ LT books } & \multicolumn{2}{l|}{ LT dissertations } \\
\cline { 2 - 7 } & \# raw & $\%$ & \# raw & $\%$ & \# raw & $\%$ \\
\hline Academic assistance & 159 & $31 \%$ & 172 & $43 \%$ & 115 & $42 \%$ \\
\hline Resources & 206 & $41 \%$ & 153 & $39 \%$ & 45 & $16 \%$ \\
\hline Moral support & 142 & $28 \%$ & 71 & $18 \%$ & 114 & $42 \%$ \\
\hline Total & 507 & $100 \%$ & 396 & $100 \%$ & 274 & $100 \%$ \\
\hline
\end{tabular}

Table 4: The frequency of occurrence of the Thanking move steps 2.2-2.4 in raw numbers and percentages 
We can see that a total of 1,177 cases of occurrences of thanks for academic assistance, resources and moral support were found in the total of 132 texts. Nearly half of them are in the English scholarly books with the largest share devoted to thanks for various types of resources provided. The most frequent category in the Lithuanian books, thanks for academic assistance, occurred more than once in each of the acknowledgments, whereas as many as 115 cases of thanks for academic assistance and 114 of them for moral support were used in $32 \mathrm{PhD}$ texts, making these two the most popular categories of gratitude in the Thanking move of the $\mathrm{PhD}$ sub-corpus.

Going back to Table 3, we can see that the third move (the Announcing move) is less frequent in all three sub-corpora. Claiming responsibility for any flaws or errors in the English and Lithuanian acknowledgments (Step 3.1) seems to be equally scarce in all three sub-corpora, whereas the dedication of the work to someone is much more pronounced in the British acknowledgments, with Lithuanian $\mathrm{PhD}$ work displaying none of this.

The following sections will look at each of the moves in more detail.

\subsubsection{The Thanking move}

As mentioned before, this is the core move of the acknowledgments genre. It occurs in all the texts, centering around three main thanking steps for academic assistance, resources and moral support. There could be several steps included into one sentence, sometimes of all three types, as in Example 1:

Once again I must thank Arthur Keaveney, who has continued to lend support and encouragement along the way [M2S4] and, in more practical terms, has helped proof-read the manuscript [M2S3] and offered much advice on publishing my work [M2S2]. (EN SB 10)

The Thanking move also contains one rarer step, which prepares the reader for the coming thanks, i.e. the Presenting participants step, which is discussed in more detail in the section below.

\subsubsection{Presenting participants step}

This step occurred in nearly half of acknowledgments and was slightly more popular in scientific books. In this step authors frequently confirm that research writing is a difficult and time consuming process and that it usually requires the help of other people. In most of the cases, this step occurred in the initial position of the Thanking move:

(2) I would like to thank the following individuals for their help and support, without which, this book would not have been accomplished. (EN SB 16) 
(3) Kaip prie kiekvienos knygos gimimo, ir prie šios prisidèjo gausus ratas žmoniu (palaikytoju, skatintoju, patareju, kritiku, bičiuliu, drangu, istoriku) <...>. (LT SB 42)

[Just like in the birth of every book, this book also enjoyed a contribution of numerous people (supporters, encouragers, advisers, critics, friends, comrades, historians).]

Hyland (2004) claims that the Presenting participants step is a part of longer, more complex acknowledgments and this was also confirmed by the data in our corpus. Since the English acknowledgments were generally longer than the Lithuanian ones, it explains why this step occurs more frequently in the English authors' books ( $64 \%$ vs $50 \%$ in LT books vs $41 \%$ in LT $\mathrm{PhD}$ theses, Table 3 ). This step is quite formulaic in character, therefore it is very similarly expressed in both languages and genres.

\subsubsection{Thanking for academic assistance}

Thanking for academic assistance involves gratitude for intellectual ideas, feedback and criticism, granting approval for publication, assisting with the analysis, and so on. The high frequency of this step shows that it is very important to thank those who contributed to the work in one way or the other. It also suggests that scientific work is never one person's work, it usually involves various types of assistance from a number of people:

(4) Visu pirma noréčiau nuoširdžiai padèkoti savo darbo vadovei prof. habil. dr. Aurelijai Usonienei už pasiūlyta ịdomia tema ir vertingas mokslines ižvalgas bei diskusijas disertacijos tema. (LT PhD 9)

[First of all I would like to sincerely thank the supervisor of my work, Prof. Dr. habil. Aurelija Usoniene for an interesting suggested topic and for valuable scientific insights and discussions.]

(5) First, I would like to thank Professor Guido Rings and Dr. Sebastian Rasinger at Anglia Ruskin University and Dr. Joseph Poulshock at Tokyo Christian University for their careful readings of my manuscripts and for providing me with valuable feedback, which enabled me to make the necessary revisions. (EN SB 16)

The difference here perhaps is mainly generic, with the tendency for $\mathrm{PhD}$ students to thank more experienced individuals, higher in academic rank, typically their supervisors and scientific committee members who reviewed the manuscript. However, there are also cases when doctoral students offer thanks to their peers for commenting on the manuscript or for fruitful academic discussions. In $\mathrm{PhD}$ work the first one of the three thanking steps to appear is typically thanks for academic assistance with 78 per cent of all $\mathrm{PhD}$ authors placing it before 
thanking for resources or moral support. Even though one could expect the first person acknowledged in $\mathrm{PhD}$ work to be the supervisor, as in Example (4), this is not always the case, with nine out of $32 \mathrm{PhD}$ theses providing thanks for other people, typically still from the academic field, but not the supervisors, who would appear later in the list. These other people would usually be first teachers or inspirational scholars, who made the students interested in the field.

While most of the scientific book authors tend to thank people equal in status, there are also cases when the book developed from the $\mathrm{PhD}$ thesis, in which case the acknowledgments resemble those of the $\mathrm{PhD}$ students and are devoted to the supervisors or examiners:

Sincere thanks are also due to my two examiners, Professor Miri Rubin and Professor Andrew Louth, for their valuable insight and excellent advice. (EN SB 16)

Though thanking for academic assistance could include a variety of aspects to be grateful for, the most usual ones in all three sub-corpora are for helpful insights, feedback and critical comments on the manuscript.

\subsubsection{Thanking for providing resources}

This step involves giving thanks for material support provided by individuals and/or institutions. The support acknowledged here ranges from access to data, permissions to use copyright materials, proofreading of the text, technical help, to providing good work conditions and financial assistance. Following Hyland (2004), types of acknowledged resources were classified into several categories, such as access to data, financial support, clerical assistance and technical help (Table 5):

\begin{tabular}{|l|l|l|l|l|l|l|}
\hline \multirow{2}{*}{ Resource type } & \multicolumn{2}{l|}{ EN books } & \multicolumn{2}{l|}{ LT books } & \multicolumn{2}{l|}{ LT dissertations } \\
\cline { 2 - 7 } & \# raw & $\%$ & \# raw & $\%$ & \# raw & $\%$ \\
\hline Access to data & 111 & $54 \%$ & 61 & $40 \%$ & 16 & $36 \%$ \\
\hline Clerical support & 22 & $11 \%$ & 28 & $18 \%$ & 8 & $18 \%$ \\
\hline Financial support & 34 & $16 \%$ & 28 & $18 \%$ & 11 & $24 \%$ \\
\hline Technical support & 39 & $19 \%$ & 36 & $24 \%$ & 10 & $22 \%$ \\
\hline Total & 206 & $100 \%$ & 153 & $100 \%$ & 45 & $100 \%$ \\
\hline
\end{tabular}

Table 5: The distribution of Thanking for resources categories across the sub-corpora in raw numbers and percentages 
The results show that access to data is the type of resources authors in all three data sets acknowledge most frequently. This category does not only include thanks for the access to datasets compiled by other people as in (7), but also access to information, pre-prints, images, permissions to use copyright materials, photographs, drawings. Here the help of libraries and various other institutions as well as individuals is greatly appreciated, especially by the British authors:

(7) Taip pat esu dèkinga dr. Ritai Juknevičienei už suteikta galimybę naudotis jos sukauptu anglu filologijos pirmo kurso tekstynu <...>. (LT PhD 12)

[I am also grateful to dr. Rita Juknevičiene for the possibility to use her selfcompiled corpus of first year English Philology students [writings].]

(8) The Gye Diaries Trust, courtesy of the Royal Opera House, London, kindly consented to the use of Frederick Gye's diaries and travel journals, and Stephen Agus has permitted the use of unpublished material. (EN SB 24)

(9) I am particularly grateful to Louis Hellman who gave me permission to use a number of his brilliant cartoons. (EN SB 33)

The second most frequent category acknowledged by the authors of books is technical assistance. Percentage wise it is the third most frequent category in $\mathrm{PhD}$ work, however, having in mind the generally low frequency of occurrences of thanking steps in $\mathrm{PhD}$ theses, the difference between the technical support category and the financial support category, which is second in frequency, is just one occurrence. The technical support is mainly provided by publishing houses with little difference of thanks expression in the two languages and genres:

(10) Nuoširdūs padèkos žodžiai priklauso ir Lietuviu literatūros ir tautosakos instituto Leidybos centro vadovui Gyčiui Vaškeliui, kurio pastangomis priešleidybinis stresas virto maloniu laukimu, kol rankraštus igis knygos pavidala. (LT SB 12) [Sincere words of thanks are also due to Gytis Vaškelis, the head of the Publishing center at the Institute of Lithuanian literature and folklore, whose efforts turned the pre-publication stress into pleasant waiting for the manuscript to become a book.]

(11) The team at Cambridge Scholars Publishing has proved remarkably supportive and efficient in bringing this book to print. (EN SB 41)

Occasionally this is the category that also involves the help of family members, especially in the scientific books data set in both languages:

(12) Secondly, [special thanks go to] my youngest son Jason Haines who has given me invaluable technical support, and assistance in inserting my images. (EN SB 19) 
(13) Lygiai taip pat esu dèkingas savo šeimai, o sūnui Mindaugui dar ir už greitaja kompiuterio darbu pagalbą. (LT SB 15)

[I am equally grateful to my family, and to my son Mindaugas also for the efficient help with computer work.]

The financial support for which the authors felt grateful included not only funding and scholarships, but also practical arrangements for which the authors did not have to pay, for example, accommodation or working space. Particularly in scientific books thanking for financial support, funding or grants was frequently quite implicit, with usually only institution mentioned and the direct act of thanking omitted:

(14) Monografija nebūtu išleista be Vilniaus universiteto Filologijos fakulteto paramos. (LT SB 3)

[The monograph would not have been published without the support of Vilnius University Faculty of Philology.]

(15) Financial support was kindly given by the Department of History at the University of York and the University of Huddersfield's School of Music, Humanities and Media. (EN SB 9)

In contrast, there are acknowledgments for the financial support which include an explicit speech act of thanking, however, these appear less frequently in the sub-corpora:

(16) Svarbus štrichas kiekvienos knygos pasirodymo istorijoje yra finansavimas, todèl dèkoju Lietuvos mokslo tarybai, kurios paskirta parama užtikrino sklandžia knygos leidyba. (LT SB 22)

[An important aspect in the history of every book is financing, therefore I thank the Research Council of Lithuania, which provided support for the smooth publication of the book.]

(17) Lastly, I would like to thank the John D. Bies Research Endowment for funding my research. (EN SB 5)

As explained by the interviewees, such expressions of acknowledgments as in (14)-(15) could be due to the fact that big national funding agencies are impersonal and, therefore, the acknowledgment of funding is typically very formal or simply phrased according to the officially stated requirements:

To me the Research Council is something non-personal, that is why I thank it very formally. (Interviewee 5, English Philology) 
If it were a private funding enterprise $<\ldots>$ then it would be necessary to express thanks explicitly. (Interviewee 1, History)

A more personal thanking statement in (17) exemplifies the idea of the interviewees that the financial support from private funds is typically acknowledged in a more personal way.

Finally, clerical support acknowledgments were the least frequent type of support in all the three sub-corpora. Clerical support was usually provided by colleagues and administrative workers, and sometimes even family members, but only in the case of scientific books.

(18) Darba spartino kolegè Irena Buračaitè. Ji parengè knygos rodykles. (LT SB 7) [The work was made faster by the colleague Irena Buračaitè. She prepared the book index.]

(19) Finally, I must thank my wife for her painstaking correction of my numberless keyboard idiosyncrasies. (EN SB 13)

$\mathrm{PhD}$ students did not have many cases of clerical support thanks and these primarily included acknowledging proofreading services or translating the summary of the dissertation into English.

\subsubsection{Thanking for moral support}

The final step in the Thanking move is more personal, with gratitude here typically expressed for friendship, encouragement, patience, care or sympathy. Thanking for moral support occurs in 68 per cent and 76 per cent of Lithuanian and English scientific book acknowledgments respectively, and it is used in every $\mathrm{PhD}$ thesis acknowledgment making it 100 per cent occurrence. For doctoral students the $\mathrm{PhD}$ thesis is their first big and serious scientific work, it is a journey of disappointments and discoveries, therefore moral support here plays a crucial role. Likewise, writing a book is a big commitment in terms of time and energy, often requiring scholars 'to steal' time from their loved ones and devote it to work. The frequency of the step suggests that for researchers it is important to express gratitude not only to academic community and colleagues, but also to the people outside of the academia, who supported them morally, never ceased to believe in them and thus contributed to their research in different, yet not less important ways.

(20) Ačiū Rolandui, mano vyrui, tèvams - Danutei ir Juozui, sesei Karolinai ir ištikimiems bičiuliams, kurie pakeldavo mano dvasia bejègiškumo ir nevilties akimirkomis. Be šios pagalbos darbas nebūtu pasiekęs dienos šviesos. (LT PhD 2) 
[Thanks to Rolandas, my husband, to my parents, Danute and Juozas, to my sister Karolina and faithful friends, who raised my spirits in the moments of helplessness and despair. Without this help, the work would have not seen the light of the day.]

(21) Finally, the most tremendous gratitude is extended to my longsuffering family: to John who has endured long weeks as a single parent whilst I indulged both the need for research and the desire to excavate and to my son Gareth and daughters Fiona, Bronwyn, and Enya, who have been waiting for Mum to finish writing this is for you. (EN SB 38)

(22) Ačiū dukrelèms, kurios kantriai laukè, kol mama parašys 'savo knygą'. (LT $\mathrm{PhD} 28)$

[Thanks to my little daughters who have been patiently waiting for Mum to finish writing 'her book'.]

Nearly identical Examples (21)-(22), where mothers are thanking their children for waiting patiently until they complete their writing, show that in the research world apart from exciting discoveries and scientific victories there are also universal emotions and feelings authors experience irrespective of language or culture.

Though thanks for moral support are usually offered for family members and close friends, they quite frequently include supervisors (in $\mathrm{PhD}$ theses) and colleagues (in scientific books).

\subsubsection{Participants of acknowledgments}

Onemore aspect of the analysis focused on the participants ofacknowledgments, i.e. individuals and institutions acknowledged by the authors in Steps 2.2-2.4 of the Thanking move. In the whole data set a total of 1,979 individuals were acknowledged and there were as many as 386 occurrences of thanks to various groups and 235 instances of acknowledgments to institutions (Table 6).

\begin{tabular}{|l|l|l|l|l|l|l|}
\hline \multirow{2}{*}{ Participants } & \multicolumn{2}{|l|}{ EN books } & \multicolumn{2}{l|}{ LT books } & \multicolumn{2}{l|}{ LT dissertations } \\
\cline { 2 - 7 } & \# raw & $\%$ & \# raw & $\%$ & \# raw & $\%$ \\
\hline Individuals & 917 & $73 \%$ & 692 & $81 \%$ & 370 & $77 \%$ \\
\hline Groups & 174 & $14 \%$ & 106 & $12 \%$ & 106 & $22 \%$ \\
\hline Institutions & 168 & $13 \%$ & 60 & $7 \%$ & 7 & $1 \%$ \\
\hline Total & 1259 & $100 \%$ & 858 & $100 \%$ & 483 & $100 \%$ \\
\hline
\end{tabular}

Table 6: The distribution of participants of acknowledgments across the three sub-corpora in raw numbers and percentages 
As can be seen in Table 6, the major share of gratitude in the scholarly work in the Humanities goes to individual people. Individual people feature in all three Thanking move steps: thanking for academic assistance, resources and moral support. This category of participants in acknowledgments is also the most heterogeneous with regard to terms of reference; here participants can be acknowledged with (1) their full academic title, (2) first name and surname, (3) first name only, or (4) family name, such as father or husband (Table 7):

\begin{tabular}{|l|l|l|l|l|l|l|}
\hline \multirow{2}{*}{ Terms of reference } & \multicolumn{2}{|l|}{ EN books } & \multicolumn{2}{l|}{ LT books } & \multicolumn{2}{l|}{ LT dissertations } \\
\cline { 2 - 7 } & \# raw & $\%$ & \# raw & $\%$ & \# raw & $\%$ \\
\hline $\begin{array}{l}\text { Academic title + first name and } \\
\text { surname }\end{array}$ & 137 & $15 \%$ & 281 & $41 \%$ & 166 & $45 \%$ \\
\hline First name and surname & 619 & $67 \%$ & 363 & $52 \%$ & 134 & $36 \%$ \\
\hline First name & 146 & $16 \%$ & 27 & $4 \%$ & 46 & $12 \%$ \\
\hline Family name & 15 & $2 \%$ & 21 & $3 \%$ & 24 & $7 \%$ \\
\hline Total & 917 & $100 \%$ & 692 & $100 \%$ & 370 & $100 \%$ \\
\hline
\end{tabular}

Table 7: Terms of reference to individuals in the three sub-corpora in raw numbers and percentages

The most popular choice in both scientific book sub-corpora is to acknowledge people by their first name and surname. However, there is a difference between the level of formality employed in the acknowledgments in the two languages. The British authors employ the academic title of the individuals they thank to a much smaller extent than the Lithuanian scholars, and the percentage of people acknowledged by their first name only is also biggest in the British sub-corpus. In the PhD sub-corpus most of the individuals acknowledged are thanked using their full academic title. This is not surprising keeping in mind that $\mathrm{PhD}$ students mostly thank their supervisors, reviewers and senior colleagues. $\mathrm{PhD}$ students also mention their family in the acknowledgments to the highest extent in the three sub-corpora. The importance to mention family in $\mathrm{PhD}$ work is also noted by our interviewees:

Everyone includes less formal acknowledgments in the dissertations, to the family members, even to their cat $<\ldots .>$. It is customary to thank closer people who most probably did not contribute a lot to the academic text, but who helped you emotionally, made you feel good or assisted in the household chores. (Interviewee 4, English Philology) 
'Groups' in Table 6 mean non-personalised references such as, for example, friends, colleagues, librarians, etc. It is the second most frequent category in all three sub-corpora. Institutions are acknowledged least frequently in all three sub-corpora and include academic and non-academic enterprises. Thanks to institutions go primarily for the financial support in all three data sets, though occasionally museums, galleries, libraries are also acknowledged for providing help with the data or permissions to use material.

The basic difference between the sub-corpora again is more in the level of details and the number of participants acknowledged. The British authors tend to mention as many individuals and institutions which contributed to the book as possible, whereas the Lithuanian authors seem to express their gratitude to those who contributed the most.

\subsubsection{The Announcing move}

This move was less frequent in the texts of Lithuanian writers and was more characteristic of the scientific books in both languages than of the doctoral dissertations acknowledgments. In Hyland's model (2004), the move includes two steps: accepting responsibility for the remaining flaws in the work and dedicating the work to someone.

\subsubsection{Accepting responsibility}

Very few texts in all three sub-corpora included this step (four in the books sub-corpus by British authors, five in the books sub-corpus by Lithuanian authors, and two in PhD work). This step immediately follows the Thanking move, and usually is in combination with such boosters as no doubt or savaime suprantama 'it goes without saying'.

(23) Savaime suprantama, kad už visus knygos trūkumus atsakau tik aš. (LT SB 35) [It goes without saying that for all the shortcomings of the book I am the only one responsible.]

(24) In spite of their contributions I have no doubt about the gaps and errors remaining in this book, for which the fault is mine alone. (EN SB 3)

The authors may be willing to strengthen the claim, so that the reader is in no doubt about who is responsible for the work and its content.

\subsubsection{Dedicating the work}

This step is dominant in the English sub-corpus with more than half of all books (58\%) including it. In the Lithuanian books dedications appeared to a 
much smaller extent with only 28 per cent of all books including it. In Hyland's (2004) data from $\mathrm{PhD}$ and MA dissertations this step occurred as the final step in the acknowledgments, however, in our sub-corpora of scientific books more dedications were placed at the beginning of the acknowledgments rather than at the end. When they appeared at the beginning, typically these were short phrases such as to/for $X$ :

To my parents, Cecilia and Barry. (EN SB 8)

For Michael. (EN SB 15)

Skiriu Erdvilui. (LT SB 37)

[I dedicate [this book] to Erdvilas.]

Placed at the beginning of the acknowledgments text with typically just the first name of the person(s) for whom the book is dedicated, such brief formulae create a very personal feel. The same practice of dedicating the book could be observed in literary works of fiction and should generally be characteristic of a book genre.

None of the dedications were found in the $\mathrm{PhD}$ dissertations, probably because it is not a completely autonomous work; here considerable help may be provided by the supervisor which could have restricted the authors from dedicating the work to the important people in their lives.

\section{Concluding remarks}

With their coherent structure and clear aims, acknowledgments are an important part of research writing. They perform a wide range of functions, not only allowing authors to express their gratitude, but also to take their own responsibilities for the work. Acknowledgments also provide an opportunity for the readers to catch a glimpse of a more personal side of the author in the view of his/her relationship with both academic community members and family and friends.

The results suggest that the British scholars place more importance on acknowledgments as they single out their thanks as separate sections, make them lengthier and express gratitude for far more individuals and institutions than the Lithuanian scholars. This is especially obvious in the case of Lithuanian doctoral students, who rarely write acknowledgments in their dissertations. The reason for this is a general tendency to orally acknowledge individuals or institutions immediately after the defence. Hyland (2004) suggests that a lack of knowledge and practice in this particular genre may also influence students' choices to 
include or exclude a written acknowledgment in a thesis. As suggested by some of our interviewees, students should be taught how to write acknowledgments just like they are taught how to compose other parts of their scientific papers, or at least they should be made aware that acknowledging practices exist in writing.

The generic structure analysis shows some differences in the distribution of moves and steps. Doctoral students tend to be more grateful for moral support than the established scholars, and they presumably receive less help in various types of resources as they express less thanks in this category. The authors of the books in both cultures seem to be quite uniform in thanking moves and steps, the major difference being the frequency of the Dedication step. The British researchers tend to be in favour of dedicating the work to somebody, typically a close person. Both experienced and novice Lithuanian scholars seem to be slightly more formal in expressing thanks, as a significant part of the acknowledgments' participants appear with their full academic titles. In contrast, the British researchers tend to be less focused on academic ranks when they thank.

Even though there were some differences between genres and cultures, the most frequent moves of acknowledgments and their formulations seem to be universal despite the cultural background of writers or the genre, and include thanking for academic assistance, resources and moral support. The moves and steps identified were not different from the previous studies (cf. Hyland 2004).

Further work could include studies on acknowledgments written by Lithuanian scholars in English or in other languages, and in other academic disciplines, as well as research on acknowledgment practices in other academic cultures. It would also be interesting to compare acknowledgment patterns in $\mathrm{PhD}$ dissertations written by Lithuanian students with those of the British $\mathrm{PhD}$ students, as such a study would be more comparable in terms of genre.

\section{Acknowledgments}

We would like to thank two anonymous reviewers for their detailed and very useful comments.

\section{Notes}

1 Aidai, Akademinė leidykla, Dailès akademinė leidykla, Generolo Jono Žemaičio Lietuvos karo akademijos leidykla, Lietuvių kalbos institutas, Lietuvių literatūros ir tautosakos institutas, Mokslo ir enciklopedijos leidybos centras, Mokslo studija, Naujasis lankas, Versus Aureus, Vilniaus pedagoginis universitetas, Vilniaus universiteto leidykla. 


\section{References}

Atkinson, D. (2003) 'Writing and culture in the post-process era.' Journal of Second Language Writing 12(1), 49-63.

Atkinson, D. (2004) 'Contrasting rhetorics/contrasting cultures: Why contrastive rhetoric needs a better conceptualization of culture.' Journal of English for Academic Purposes 3(4), 277-289.

Bondi, M. and Lorés-Sanz, R. (eds) (2014) Abstracts in Academic Discourse: Variation and Change. Bern: Peter Lang.

Bowker, L. and Pearson, J. (2002) Working with Specialized Language: A Practical Guide to Using Corpora. London and New York: Routledge.

Cheng, W. (2012) 'A contrastive study of master thesis acknowledgment by Taiwanese and North American students.' Open Journal of Modern Linguistics 2(1), 8-17.

Clyne, M. (1987) 'Cultural differences in the organization of academic texts: English and German.’ Journal of Pragmatics 11(2), 211-247.

Connor, U. M. and Moreno, I. A. (2005) 'Tertium comparationis: A vital component in contrastive research methodology.' In: Bruthiaux, P., Atkinson, D., Eggington, W., Grabe, W. and Ramanathan, V. (eds) Directions in Applied Linguistics: Essays in Honor of Robert B. Kaplan. England: Multingual Matters. 153-164.

Cronin, B., McKenzie, G. and Rubio, L. (1993) 'The norms of acknowledgment in four humanities and social sciences disciplines.' Journal of Documentation 49(1), 29-43.

Díaz-Faes, A. A. and Bordons, M. (2014) 'Acknowledgements in scientific publications: Presence in Spanish science and text patterns across disciplines.' Journal of the Association for Information Science and Technology 65(9), 1834-1849.

Duszak, A. (ed.) (1997) Culture and Styles of Academic Discourse. Berlin and New York: Mouton de Gruyter.

Fløttum, K., Dahl, T. and Kinn, T. (2006) Academic Voices: Across Languages and Disciplines. Amsterdam and Philadelphia: John Benjamins.

Giannoni, D. S. (2002) 'Worlds of gratitude: A contrastive study of acknowledgment texts in English and Italian research articles.' Applied Linguistics 23(1), 1-31.

Hinds, J. (1987) 'Reader versus writer responsibility: A new typology.' In: Connor, U. and Kaplan, R. B. (eds) Writing across Languages: Analyses of L2 Text. Reading, MA: Addison-Wesley. 141-152.

Holliday, A. (1999) 'Small cultures.' Applied Linguistics 20(2), 237-264.

Hopkins, A. and Dudley-Evans, T. (1988) 'A genre-based investigation of the discussion sections in articles and dissertations.' English for Specific Purposes 7(2), 113-121.

Hyland, K. (2003) 'Dissertation acknowledgments: The anatomy of Cinderella genre. Written Communication 20(3), 242-268.

Hyland, K. (2004) 'Graduates' gratitude: The generic structure of dissertation acknowledgments.' English for Specific Purposes 23(3), 303-324.

Hyland, K. (2005) Metadiscourse: Exploring Interaction in Writing. London and New York: Continuum.

Hyland, K. (2008) 'Persuasion, interaction and the construction of knowledge: Representing self and others in research writing.' International Journal of English Studies 8(2), 1-23.

Hyland, K. (2009) Academic Discourse. London: Continuum.

Hyland, K. and Bondi, M. (eds) (2006) Academic Discourse Across Disciplines. Bern: Peter Lang. 
Hyland, K. and Tse, P. (2004) “ "I would like to thank my supervisor”.' Acknowledgments in graduate dissertations.' International Journal of Applied Linguistics 48(2), 259-275.

Lorés, R. (2004) 'On RA abstracts: From rhetorical structure to thematic organization.' English for Specific Purposes 23(3), 280-302.

Mauranen, A. (1993) 'Cultural differences in academic discourse - problems of a linguistic and cultural minority.' In: Löfman, L., Kurki-Suonio, L., Pellinen, S., and Lehtonen, J. (eds) The Competent Intercultural Communicator: AFinLA Yearbook. Helsinki: AFinLA. 157-174.

Povolná, R. (2016) 'Cross-cultural analysis of conference abstracts.' Discourse and Interaction 9(1), 29-48.

Sala, M. (2008) 'Argumentative styles as cultural identity traits in legal studies.' Linguistica e Filologia 27, 93-113.

Šinkūnienė, J. (2014) Lietuviškojo humanitariniu ir socialinių mokslu diskurso ypatybès: Mokslostudija [Insights into Lithuanian scientific discourse of the Humanities and Social Sciences]. Vilnius: VU leidykla.

Suomela-Salmi, E. and Dervin, F. (eds) (2009) Cross-linguistic and Cross-cultural Perspectives on Academic Discourse. Amsterdam and Philadelphia: John Benjamins.

Swales, J. M. (2004) Research Genres: Explorations and Applications. Cambridge: Cambridge University Press.

Jolanta Šinkūnienè is Associate Professor of English Linguistics at the Faculty of Philology, Vilnius University, Lithuania. Her research interests focus on research writing patterns and epistemological traditions of various disciplines and cultures, academic rhetoric, elements of persuasion in academic discourse, research publication practices, evaluation of research, academic identity aspects.

Address: Dr. Jolanta Šinkūnienė, Institute of English, Romance and Classical Studies, Department of English Philology, Faculty of Philology, Vilnius University, Universiteto 5, LT-01513 Vilnius, Lithuania. [e-mail: jolanta.sinkuniene@flf.vu.lt]

Gabrielė Dudzinskaitė holds a BA degree in English Philology obtained at Vilnius University, Lithuania. Her research interests include cross-linguistic and cross-disciplinary aspects of academic text construction, especially the macrostructure and metadiscoursal features of academic texts.

Address: Gabrielė Dudzinskaitè, Vivulskio 18-11, LT-03115, Vilnius, Lithuania. [e-mail: dudzinskaite@gmail.com] 